\title{
Romanismy v Novém občanském zákoníku a jejich francouzské ekvivalenty
}

\author{
Romanisms in the Czech New Civil Code \\ and their French Equivalents
}

\author{
Kateřina Hodková* \\ University of South Bohemia in České Budějovice, Czech Republic
}

\begin{abstract}
The purpose of this study is to present findings from original linguistic research, which combines two linguistic disciplines applied to language for specific purposes, more precisely to legal language: etymology and translatology. The study aims to draw a definitive conclusion regarding the presence of romanisms in the so-called Nový občanský zákoník (New Civil Code) of the Czech Republic while also trying to demonstrate the process of the translation of legal terms and the various obstacles that the translator may encounter. Special attention is also paid to the equivalence of legal concepts. The methodology was as follows: Firstly, romanisms were extracted from the text of Nový občanský zákoník; secondly, selected terms containing romanisms were translated into French using primarily existing French laws, and thirdly, the Czech terms and their French translations were compared from various perspectives. The proposed French translations were also compared to translations that can be found in the official French translation of Nový občanský zákoník in order to evaluate how appropriate the official translations are for legal concepts and existing French legal terminology. According to the findings of this research, it can be stated that the text of Nový občanský zákoník contains 32 romanisms in various forms and as parts of numerous terms. The romanisms were all of either French or Italian origin. As for the equivalence of concepts, the tested sample included examples of perfect equivalence, partial equivalence and zero equivalence. The obstacles encountered during the translation include partial and zero equivalence, missing legal definition, rivalry of multiple different translations, and others. The study also offers possible solutions to these problems. After examining the official translations, it was found that while some of the translations are usable without much problem, others can cause severe misinterpretations.
\end{abstract}

\section{Keywords}

romanisms, loanwords, terminology, etymology, Nový občanský zákoník, conceptual equivalence

\section{Úvod}

Terminologie a její studium představuje aktuální téma lingvistického výzkumu v mnoha perspektivách. Zmínit lze mimo jiné studium termínů s ohledem na jejich tvorbu, lexikum či mezi-

\footnotetext{
* Corresponding Author: Kateřina Hodková, Ústav romanistiky, Filozofická fakulta Jihočeské univerzity v Českých Budějovicích, Branišovská 31a, 37005 České Budějovice. E-mail: katerina.hodkova@gmail.com.
} 
jazykový překlad a komparaci z hlediska jejich ekvivalence. Tato poslední zmiňovaná perspektiva je podstatná zejména pro oblast právní terminologie. $\mathrm{K}$ překladům textů právní povahy, at už se jedná o soudní překladatelství, překlad právních dokumentů či odborných publikací, dochází dennodenně a významové nuance mezi právními koncepty a termíny v různých právních řádech mohou mít kritické dopady. Specifickou situaci s ohledem na ekvivalenci konceptů pak představuje překlad právních pramenů Evropské unie, nebot je vyžadováno, aby všechny jazykové verze téhož pramenu byly ekvivalentní. Překladatelé přitom věnují pozornost nejen sémantické analýze právních konceptů a jejich komparaci, ale rovněž tvorbě neologismů, s čímž souvisí znalost úzu cílového jazyka i cílového právního jazyka.

Tato jazykovědná studie se věnuje problematice právní terminologie ze dvou odlišných perspektiv. První z nich je etymologická a zabývá se přítomností romanismů, tedy slov původem z románských jazyků, v rámci terminologie vybraného českého právního předpisu (konkrétně se jedná o tzv. Nový občanský zákoník). Druhou část výzkumu, která navazuje na první zmíněnou, představuje mezijazykový překlad vybraných právních termínů z češtiny do francouzštiny, přičemž nedílnou součástí tohoto procesu je komparace právních konceptů.

Tato studie si klade za cíl nejen získání ucelené představy o výskytu přejímek z románských jazyků ve vybraném českém právním předpisu co do jejich počtu a využití v lexiku právních termínů, ale rovněž demonstraci obtíží různého typu, s nimiž se překladatel při překladu právní terminologie může setkat. Provedena bude rovněž analýza překladů vybraných termínů v oficiálním překladu občanského zákoníku do francouzštiny s ohledem na to, zda respektují existující francouzskou právní terminologii a zda by bylo možné je použít v překladech právních dokumentů. Součástí této studie jsou výsledky překladatelského procesu provedeného v rámci tohoto výzkumu.

\section{Metodologie a předpokládané výsledky}

První fáze výzkumu zahrnovala etymologickou a lexikografickou práci, během níž byla věnována pozornost přejímkám, konkrétně romanismům (slovům přejatých z románských jazyků, tedy francouzštiny, italštiny, španělštiny, portugalštiny a rumunštiny), v českém jazyce. Jako vzorek, v němž byl výskyt romanismů zkoumán, byl vybrán zákon č. 89/2012 Sb., občanský zákoník (také známý jako „Nový občanský zákoník“, dále jen „NOZ“), ve znění platném od 1. ledna 2018. Postup sběru romanismů byl následující: text zákoníku byl přečten v celé délce a etymologie jednotlivých lexémů ověřena v několika etymologických slovnících a databázích (Holub, Kopečný 1952; Machek 1968; Rejzek 2015; Centre National des Ressources Textuelles et Lexicales nedat.; Online Etymology Dictionary nedat.). Po extrahování romanismů a slovních spojení obsahujících romanismy byla zahájena druhá fáze, kterou představoval překlad vybraných právních termínů obsahujících alespoň jeden romanismus do francouzštiny. Obzvláštní zřetel byl přitom brán na ekvivalenci právních konceptů. Při překladu byly využity české a francouzské právní prameny, francouzský výkladový slovník Vocabulaire juridique (Cornu 2008) a podpůrně taktéž překladové odborné česko-francouzské a francouzsko-české slovníky.

Součástí ani cílem této práce není zkoumání původu daných právních konceptů (tj. zda se jedná o původní české právní koncepty, nebo o koncepty přejaté z cizích právních předpisů). Za romanismy se považují lexikální jednotky přejaté z románských jazyků, nikoli právní koncepty původem z právních předpisů Francie, Itálie, Španělska, Portugalska a Rumunska, popř́ípadě dalších zemí, kde je úředním jazykem některý románský jazyk.

Před započetím výzkumu samotného byly očekávány následující výsledky:

1) Celkový počet různých (tj. nederivovaných od téhož základu) přejímek z románských jazyků se bude pohybovat v rozpětí 80-150 romanismů, přičemž nejpočetnější skupinu budou představo- 
vat italianismy ${ }^{1}$ (důvodem pro tento předpoklad byla skutečnost, že jednou z tematických oblastí, které obsahují italianismy, je v češtině bankovnictví). Galicismy, hispanismy a lusitanismy budou rovněž zastoupeny. Tento odhad byl stanoven na základě celkové počtu romanismů v češtině (viz níže).

2) Z hlediska slovních druhů budou nalezené romanismy nejvíce zastoupeny podstatnými a přídavnými jmény, v menší míře slovesy a př́islovci.

3) Víceslovná spojení obsahující romanismy budou početnější než jednoslovné romanismy.

4) Z hlediska ekvivalence právních konceptů bude mít největší zastoupení částečná ekvivalence, přičemž dokonalá ekvivalence bude mít několik málo zástupců a nulová ekvivalence žádného.

\section{Přejímání slov z cizích jazyků}

Snad s výjimkou jazyků izolovaných uzavřených společenství všechny jazyky prošly a stále procházejí procesem přejímání neboli vypůjčování slov z jiných jazyků, at už přímo nebo díky zprostředkujícím jazykům. Vzájemný styk jazyků probíhal v minulosti prostřednictvím obchodníků, umělců, učenců, cestovatelů a dalších, v současnosti lze jistou roli přičíst rovněž moderním komunikačním technologiím. K vypůjčování slov může docházet spontánně či záměrně (např. obrozenci v době národního obrození záměrně zaváděli výpůjčky z jiných slovanských jazyků, aby rozšíríili slovní zásobu češtiny a dostali ji na roveň němčině). Nejčastějším důvodem pro přejímání slov je potřeba pojmenovat nové či neznámé skutečnosti, přičinou ale může být například také snaha najít vhodnější (např. přesnější či společensky přijatelnější) pojmenování nějakého jevu. Někdy dochází k přejímání cizích slov i v případě, že jazyk již má pro danou skutečnost vhodný název. Stávající a přejaté slovo se ale v takových situacích obvykle liší stylisticky (např. jedno ze slov je hovorové nebo naopak vysoce odborné). Může dojít rovněž k vypůjčení více slov ze stejného jazyka, která naleží k téže tematické oblasti (např. slova související s feudalismem z francouzštiny nebo slova související s křestanstvím z latiny).

Po svém vypůjčení do jiného jazyka prochází dané slovo procesem adaptace neboli přizpůsobení jazykovému úzu nového jazyka. Adaptace může probíhat na úrovni ortoepické (uzpůsobení výslovnosti), ortografické (přizpůsobení pravopisu), morfologické (např. zavedení skloňování), sémantické (významový posun) či stylistické (např. slovo získává expresivní příznak). Některé výpůjčky jsou adaptované do té míry, že bez znalosti příslušné etymologie je takřka nemožné je identifikovat. Na druhou stranu jiné si zachovávají určité cizí znaky. V češtině jsou to např. neobvyklé hlásky a grafémy $(\mathrm{G}, \mathrm{F}, \mathrm{X}, \mathrm{Q}, \mathrm{W})$, neobvyklé kombinace hlásek (např. EU, OA, IO a další, ale také Y po typicky měkké souhlásce a naopak), neobvyklá deklinace (např. téma) či její absence (např. želé) (Blatná 1999; Čechová et al. 2000; Daneš 2009; Hauser 1980; Karlík, Nekula, Rusínová 2003; Svobodová 2007, 2009; Šmilauer 1972).

Co se týká romanismů, nejpočetnější skupinu čítající přes 3000 slov tvoří galicismy (přejímky z francouzštiny) (Pešek 2017), následované italianismy (přejímky z italštiny) (Radimský 2017a), jejichž počet se pohybuje mezi 2000-3000 slov. Zbylé skupiny romanismů jsou výrazně méně početné - hispanismy (přejímky ze španělštiny) představuje okolo 140 slov, lusitanismy (přejímky z portugalštiny) okolo 30 slov a rumunismy (přejímky z rumunštiny) necelých 10 slov (Radimský 2017b). Je třeba zmínit, že ačkoli se románské jazyky postupně vyvinuly z latiny, přejímky z latiny se za romanismy nepovažují.

Různá jazyková společenství zaujímají vůči přejatým slovům různé postoje. V některých zemích je jazyková politika ohledně vypůjčených slov i ukotvena v právních pramenech. Ve Francii je platný zákon „loi no 94-665 du 4 août 1994 relative à l'emploi de la langue française“ (volně přeloženo „zákon o užívání francouzského jazyka“, známý také pod názvem „loi Toubon“ podle

\footnotetext{
${ }^{1}$ Lze se setkat také s označením italismy.
} 
svého tvůrce Jacquese Toubona) a s ním související prováděcí předpis „décret du 3 juillet 1996 relatif à l'enrichissement de la langue française“ (volně přeloženo „dekret o obohacování francouzského jazyka“"). Tyto dva právní předpisy chrání jazykové dědictví francouzštiny před vlivem cizích jazyků mimo jiné tím, že ustanovují orgány pro tvorbu neologismů a že určité instituce musejí povinně dávat přednost francouzským slovům oproti výpůjčkám, mají-li na výběr.

V České republice podobné nařízení neexistuje (byt v 90. letech 20. století existovaly snahy o kodifikaci legislativy týkající se ochrany českého jazyka), nicméně Legislativní pravidla vlády (Vláda ČR 2018), která upravují tvorbu nových právních předpisů, výslovně stanovují v čl. 40 odst. 4 následující: „Cizích slov lze použít jen výjimečně, jsou-li součástí užívané právní terminologie, nebo uživá-li se jich běžně v jazyce upravovaného oboru a nelze je dost vhodně nahradit českým pojmem. " Obdobná formulace se nachází i v důvodové zprávě k NOZ (Nečas, Pospíšil 2012).

\section{Romanismy v občanském zákoníku}

Při prozkoumání slovní zásoby NOZ lze konstatovat, že jeho autoři dodrželi výše zmíněné zásady týkající se cizích slov v českých právních předpisech, nebot převážná většina použitých lexémů jsou slova českého či praslovanského původu. Z př̀jatých slov tvoří nejpočetnější skupinu latinismy (např. rejstř́lk, konkurs, korporace). Ve větším počtu jsou rovněž zastoupeny přejímky z řečtiny, tedy grécismy (např. genetický nebo pseudonym), a z angličtiny neboli anglicismy (např. šek, digitální). Ve velmi omezeném počtu se zde vyskytují přejímky z němčiny (např. pacht), arabštiny (např. alkohol), holandštiny (např. loterie) či ruštiny (např. české vlajka je derivováno z ruského vlát).

Co se týká romanismů, v NOZ se nachází 32 různých romanismů. Je tedy zřejmé, že očekávaný počet přejímek z románských jazyků v NOZ výrazně převýšil jejich skutečný stav. Za jeden a téže romanismus se přitom považují všechny formy odvozené od stejného základu (tedy např. kontrola, kontrolor, kontrolní a kontrolovat se nepočítají jako čtyři romanismy, ale pouze jako jeden). Jako slovní druhy převládala substantiva a adjektiva, v omezené míře bylo možné najít verba a adverbia, přičemž tento zjištěný stav věcí odpovídá očekávaným výsledkům.

Nejpočetnější skupinu romanismů tvoří galicismy (23 různých přejímek) následované italianismy (9 různých přjímek). Naopak hispanismy a lusitanismy v rozporu s očekávanými výsledky nejsou zastoupeny vůbec, byt absence rumunismů byla předpovězena správně.

Zatímco některé romanismy se v celém NOZ objevují pouze jedinkrát, jiné se opakují, a to včetně různých derivovaných forem a různých slovních spojení. Pouze jednou se v NOZ vyskytují romanismy orientace, respektovat, garáže, turistický, pasový, loajalita, ministerstvo a diplomatický. Celkový počet výrazů obsahujících romanismy v NOZ činí 129, přičemž převažují víceslovná spojení, jak bylo očekáváno. Všechna syntagmata obsahují pouze jeden romanismus, ovšem až na dvě výjimky. Těmi jsou slovní spojení investiční riziko a rizika mimo kontrolu podnikatele spojená s poskytovanou finančni službou, která zahrnují dva, respektive tři romanismy.

Tabulka 1 přehledně uvádí všechny nalezené romanismy ve formě, v níž se chronologicky od začátku NOZ poprvé v zákoníku vyskytují, jejich etymologický původ a první místo výskytu. Kompletní seznam všech forem a slovních spojení může čtenář najít v kvalifikační práci, z níž tato studie vychází (Hodková 2018). 
Tabulka 1: Nalezené romanismy

\begin{tabular}{|c|c|c|c|}
\hline & romanismus & etymologie & první výskyt v NOZ \\
\hline 1. & kontrola & přes něm. z fr. contrôle & $\S 6$ odst. 2 \\
\hline 2. & organizovaný & přes něm. z fr. organiser & $\S 20$ odst. 1 \\
\hline 3. & reklamní & přes něm. z fr. réclame & $\S 34$ \\
\hline 4. & riziko & $\mathrm{z}$ it. risico, risco z fr. risquer & $\S 103$ \\
\hline 5. & adresa & $\mathrm{z}$ fr. adresse a adresser & $\S 120$ odst. 1 \\
\hline 6. & likvidace & $\mathrm{z}$ it. liquidare & $\S 129$ odst. 2 \\
\hline 7. & rasa & $\mathrm{z}$ it. razza nebo fr. race & $\S 145$ odst. 1 písm. a) \\
\hline 8. & technický & přes něm. $\mathrm{z}$ fr. technique & $\S 158$ odst. 2 \\
\hline 9. & loajalita & z fr. loyal & $\S 159$ odst. 1 \\
\hline 10. & projekt & přes něm. z fr. projet & $\S 292$ odst. 1 \\
\hline 11. & kapitál & přes něm. z it. capitale & $\S 310$ písm. e) \\
\hline 12. & investiční & přes angl. $\mathrm{z}$ it. investire & $\S 328$ odst. 1 \\
\hline 13. & banka & $\mathrm{z}$ it. banco, banca & $\S 331$ odst. 2 \\
\hline 14. & financování & přes něm. z fr. finances & $\S 342$ odst. 1 písm. a) \\
\hline 15. & fond & přes něm. z fr. fond & $\S 349$ odst. 1 \\
\hline 16. & firma & $\mathrm{z}$ it. firma & $\S 422$ \\
\hline 17. & prokura & přes něm. z it. procura & $\S 450$ odst. 1 \\
\hline 18. & kupón & $\mathrm{z}$ fr. coupon & $\S 523$ odst. 1 \\
\hline 19. & diplomatický & $\mathrm{z}$ fr. diplomate & $\S 668$ \\
\hline 20. & respektovat & přes něm. z fr. respect & $\S 687$ odst. 2 \\
\hline 21. & režim & $\mathrm{z}$ fr. régime & $\S 708$ odst. 2 \\
\hline 22. & orientace & $\mathrm{z}$ fr. orienter $\mathrm{z}$ fr. orient & $\S 907$ odst. 2 \\
\hline 23. & inženýrský & $\mathrm{z}$ fr. ingénieur & $\S 1267$ odst. 1 \\
\hline 24. & ministerstvo & přes něm. z fr. ministre & $\S 1545$ odst. 1 \\
\hline 25. & kvitance & $\mathrm{z}$ fr. quittance $\mathrm{z}$ fr. quitte & $\S 1614$ \\
\hline 26. & akreditiv & $\mathrm{z}$ fr. accréditif $\mathrm{z}$ it. credito & $\S 1909$ \\
\hline 27. & provize & přes něm. $\mathrm{z}$ it. provvisione, provvigione & $\S 2445$ odst. 1 \\
\hline 28. & inkasní & $\mathrm{z}$ it. incasso & $\S 2471$ odst. 2 \\
\hline 29. & invalidita & $\mathrm{z}$ fr. invalide & $\S 2517$ odst. 2 \\
\hline 30. & pasový & přes něm. z fr. passe-port & $\S 2524$ \\
\hline 31. & turistický & přes něm. z fr. tour & $\S 2527$ odst. 2 písm. b) \\
\hline 32. & garáže & $\mathrm{z}$ fr. garage & $\S 2945$ odst. 1 \\
\hline
\end{tabular}

\section{Právní jazyk, právní koncepty a jejich překlad}

Právní jazyk coby jazyk právních textů je odborným jazykem a spadá pod spisovný jazyk. Charakteristickým rysem jeho lexika jsou termíny, ustálená slovní spojení a jazykové šablony. Stěžejní roli mají především termíny, které označují konkrétní právní skutečnosti a jejich význam je přesně definován (Cornu 2005; Tomášek 2003). Tento význam se nazývá právní koncept (dále jen „koncept“). Překlad textů právního jazyka je ovšem oproti překladu textů z jiných oblastí lidského vědění v jistém směru komplikovanější. Zatímco například v biologii se „pouze“ používají jiné kódy (jazyky) pro označení totožných konceptů, v právu jsou koncepty (bylo by možné také říct právní instituty) v právních úpravách jednotlivých zemí obvykle odlišné (výjimkou jsou ovšem právní předpisy Evropské unie, nebot ty jsou vypracovány v úředních jazycích všech členských zemích 
a jednotlivé jazykové verze jsou navzájem dokonale ekvivalentní2 ${ }^{2}$. Co do podobnosti konceptů se proto rozlišují tři stupně: dokonalá ekvivalence (koncepty jsou zcela totožné), částečná ekvivalence (koncepty se do určité míry překrývají, ale existují mezi nimi významové rozdíly) a nulová ekvivalence (daný koncept nemá v druhém jazyce žádný protějšek). S koncepty se pojí i další obtíže týkající se překladu právního jazyka jako například změny v konceptech v průběhu let (např. kvůli novelizacím) nebo situace, kdy jednomu termínu v jednom jazyce odpovídá více termínů v jiném jazyce a naopak (Radimský 2004, 2008).

Překladatel by tedy neměl pouze mechanicky překládat z jednoho jazyka do druhého (Jakobson 1959), ale rovněž by měl zkoumat ekvivalenci konceptů v obou právních systémech. Právní jazyk se na rozdíl od jiných odborných jazyků vyznačuje poměrně vysokou mírou víceznačnosti, a tak nejen z tohoto důvodu by prvním krokem při mezijazykovém překladu (tj. překladu z jednoho jazyka do druhého) měl být vnitrojazykový překlad, během něhož se překladatel důkladně seznamuje s označovaným právním konceptem. Teprve poté by měl přistoupit k mezijazykovému překladu, jehož první fází by mělo být seznámení se s obdobnými koncepty v právních předpisech cizí země a určení míry jejich ekvivalence s výchozím konceptem. Jedná-li se o případ dokonalé ekvivalence, cizí termín lze obvykle bez dalších obtíží použít při překladu. Složitější situace nastává, pokud se jedná o částečnou ekvivalenci. Záleží pak na uvážení překladatele, zda v případě částečné ekvivalence přistoupí $\mathrm{k}$ vytvoření nového termínu, nebo zda použije při překladu již existující termín, který ovšem neoznačuje zcela totožný koncept. V případě nulové ekvivalence nezbývá než vytvořit neologismus, opsat daný koncept či případně zkusit najít daný koncept v terminologii již neplatných právních předpisů daného státu. Výsledný překlad by měl vždy odpovídat úzu cílového jazyka a cílového právního jazyka, k čemuž překladateli napomáhají překladatelské postupy (Darbelnet, Vinay 1977; Tionová 1992; Tomášek 2003), zvláště jedná-li se o typologicky odlišné jazyky (Černý 1998; Skalička 2004).

Vzhledem k počtu faktorů, které ovlivňují překlad právního jazyka, lze říci, že překladatel by měl nejen ovládat výchozí a cílový jazyk, ale měl by mít také povědomí o daných právních prostředích, sledovat vývoj právních předpisů a rovněž znát jazykový úzus užívaný v právních předpisech daného státu.

\section{Překlad vybraných romanismů}

Vzhledem k vysokému počtu nalezených termínů obsahujících romanismy v první části výzkumu se druhá část práce věnuje překladu jen několika vybraných termínů, a to takových, které obsahují galicismy. Do překladu byla zařazena také dvě výše zmíněná slovní spojení investiční riziko (dva italianismy) a rizika mimo kontrolu podnikatele spojená s poskytovanou finanční službou (dva italianismy a jeden galicismus) z toho důvodu, že jejich součástí je více romanismů než jeden.

K překladu byly záměrně zvoleny takové výrazy, které je možné považovat za právní termíny. Jako takové by měly označovat unikátní právní koncept, který by měl být nějakým zpơsobem definovaný v právních předpisech České republiky (Petrů 2015). Tabulka 2 zobrazuje seznam právních termínů obsahujících romanismy určených k překladu. Romanismy jsou od slov nerománského původu odlišeny podtržením.

\footnotetext{
${ }^{2}$ Viz Smlouva o Evropské unii (čl. 55 odst. 1) a Nařízení č. 1 o užívání jazyků v Evropském hospodářském společenství (čl. 3).
} 
Tabulka 2: Termíny zvolené $k$ překladu

\begin{tabular}{|c|c|c|c|}
\hline 1. & diplomatická mise & 9. & kupónový arch \\
\hline 2. & dokumentární akreditiv & 10 . & $\underline{\text { kvitance }}$ \\
\hline 3. & finanční záruka & 11. & $\begin{array}{l}\text { rizika mimo kontrolu podnikatele } \\
\text { spojená s poskytovanou finanční } \\
\text { službou }\end{array}$ \\
\hline 4. & $\underline{\text { invalidita }}$ & 12. & zákonný režim \\
\hline 5. & investiční riziko & 13. & smluvený režim \\
\hline 6. & inženýrská sít & 14. & 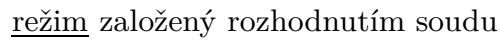 \\
\hline 7 . & klamavá reklama & 15. & srovnávací reklama \\
\hline 8. & kontrolní komise & 16. & svěřenský fond \\
\hline
\end{tabular}

V návaznosti na výše zmíněné teoretické poznatky týkající se překladu právního jazyka je třeba zmínit postup, který byl použit při překladu vybraných právních termínů v rámci této studie. Při překladu se postupovalo následujícím způsobem: Nejprve bylo zjištěno, jak české právní předpisy platné v době výzkumu definují koncept, který daný termín označuje. V další fázi proběhly pokusy o nalezení jeho ekvivalentu ve francouzských (tj. platných na území Francie) právních předpisech. Využíván byl také výkladový slovník Vocabulaire juridique (Cornu 2008) a podpůrně rovněž několik česko-francouzských a francouzsko-českých slovníků tematicky zaměřených na lexikum z oblasti práva či obchodu (Dubský, Dubský, Vlasák 1998; Kozmová, Brouland 2013; Larišová 2008; Le Docte 1997; Pataki 1997). V dalším kroku byla určena míra ekvivalence daných konceptů v českém a francouzském právu. Nakonec byl vybrán vhodný překlad daného termínu z češtiny do francouzštiny, přičemž tato volba byla krátce odůvodněna. Tento postup se opakoval u všech zkoumaných termínů.

Následující část této studie se bude stručně věnovat rozboru a překladu vybraných termínů v souladu s výše zmíněným postupem. Detailní popis jednotlivých právních konceptů a argumentaci pro konkrétní navrhované překlady může čtenář najít v kvalifikační práci, z níž tato studie vychází (Hodková 2018).

1. Diplomatická mise je definována mezinárodní úmluvou Vídeňská úmluva o diplomatických stycích. Tuto úmluvu přijala jak České republika, tak Francie. Je tedy zřejmé, že v obou právních řádech je koncept, který je v českém právu označovaný jako diplomatická mise, totožný, a jedná se tedy o dokonalé ekvivalenty. Při pohledu do francouzské verze této mezinárodní smlouvy lze snadno najít i odpovídající francouzský překlad, jímž je mission diplomatique. Je však třeba mít na paměti, že se jedná spíše o obecný výraz a při překladu konkrétních diplomatických misí je nutné s ním zacházet opatrně, nebot některé diplomatické mise již mají svůj zavedený český název.

2. Dokumentární akreditiv je v českém právu upraven v NOZ (§2690-§2692), ovšem ve francouzském právu nijak definován není, ačkoli tento nástroj užívaný v mezinárodním obchodním styku není ve Francii neznámý. Slovníky nabízejí několik různých překladů (accréditif documentaire, lettre de crédit documentaire, crédit documentaire). Slovník Vocabulaire juridique přitom uvádí u termínu crédit documentaire takovou definici, která odpovídá definici v českém NOZ. $\mathrm{Z}$ toho důvodu se termín crédit documentaire zdá jako nejvhodnější překlad, i když i zbylé př̌eklady se zdají být použitelné.

3. Finančni záruka je jedním z druhů finančního zajištění dluhu. V českém právu je upravena v NOZ (§ 2029-§ 2039). Slovníky navrhují jako překlad slova záruka termíny garantie, caution nebo cautionnement. Při zkoumání úpravy těchto výrazů ve francouzském právu se zdá, že nejblíže je české finanční záruce výraz cautionnement. Nicméně ten je v Code civil (art. 2288) v jistých 
směrech upravený jinak než finanční záruka v NOZ. V některých ohledech je mnohem detailnější, jiné opomíjí. Podle NOZ např́klad vzniká finanční záruka na základě písemného dokumentu, což není u cautionnement nijak stanoveno. Vzhledem k těmto významovým nuancím se nejedná o dokonalou ekvivalenci, ale pouze o částečnou. Jako výsledný překlad je navrhováno slovní spojení cautionnement financier, které postihuje podobnost cautionnement a finanční záruky, ale díky adjektivu financier zároveň specifikuje, že se jedná o zvláštní druh cautionnement.

4. Invalidita není v českém právu upravena v NOZ, byt NOZ s tímto termínem operuje, ale v zákoně o důchodovém pojištění (zákon č. 155/1995 Sb., o důchodovém pojištění), a to jako pokles pracovní schopnosti jedince. Podle míry poklesu pracovní schopnosti se dělí na tři stupně. Ve francouzském právu existuje termín invalidité (Code de la sécurité sociale: art. L341-1), který rovněž označuje pokles pracovní schopnosti a rovněž se dále člení na tři stupně, ovšem nikoli podle poklesu pracovní schopnosti, ale podle míry samostatnosti dané osoby. Nejedná se tedy o dokonalou ekvivalenci právních konceptů, ale i tak se jeví použití invalidité jako překladu českého invalidita jako vhodné. $\mathrm{V}$ obou případech se nejedná o plnou pracovní neschopnost a u obou se posuzují fyzické i mentální předpoklady jedince. Navíc je invalidité součástí i dalších souvisejících termínů (nap̌r. pension d'invalidité - invalidni důchod). Alternativním překladem by teoreticky mohl být termín incapacité (Code de la sécurité sociale: art. L433-1), ovšem ten francouzské právo definuje jako neschopnost pracovat následkem úrazu nebo nemoci z povolání, což neodpovídá českému invalidita.

5. Investiční riziko není nijak definováno ani v české, ani ve francouzské právní úpravě. Rizik spojených s investicemi může být mnoho druhů, ovšem kontext NOZ, v němž se tento termín nachází, nijak neupřesňuje nebo nepřibližuje, o jaký druh rizika se jedná. Ve francouzském právu se lze v podobně vágním a neurčitém kontextu setkat s výrazy risque d'investissement (např. Code monétaire et financier: art. L214-127) a risques afférents à l'investissement (např. Code de la consommation: art. L122-23). Může se jednat o neurčitost záměrnou, aby bylo možné dané ustanovení aplikovat na co nejvíc případů v praxi (Cornu 2005). Oba termíny se zdají ve své obecnosti a neurčitosti jako přijatelné překlady $\mathrm{k}$ investičnímu riziku, nicméně za vhodnější by mohl být považován termín risque afférent à l'investissement (tedy modifikace výše zmíněného termínu z plurálu do singuláru), nebot v tomto výrazu je vztah mezi slovy risque a investissement explicitněji vyjádřený. Vzhledem k tomuto a rovněž k výše zmíněným okolnostem se zdá, že tento navrhovaný překlad a investiční riziko se dají považovat za dokonalé ekvivalenty.

6. Inženýrská sît je v NOZ (§1267) upravena jako vodovodní, kanalizační, energetické nebo jiné vedení. Při zkoumání francouzských právních předpisů lze narazit na několik zmínek o podobných sítích (např. Code de l'urbanisme: art. L111-12; Code de la construction et de l'habitation: art. R*129-1). Vždy se však jedná o jakýsi výčet druhů sítí, jehož konkrétní podoba se v různých právních předpisech mění (např. Code de l'urbanisme uvádí v art. L111-12 výraz réseaux d'électricité, d'eau, de gaz ou de téléphone, v art. R151-1 zmiňuje zase réseaux d'assainissement). Francouzské právo tedy patrně koncept inženýrské sítě zná, ovšem nemá pro něj termín, který by v sobě koncentroval všechny typy inženýrských sítí. Vzhledem k úzu při popisu inženýrských sítí ve francouzském právu má navrhovaný překlad podobu réseaux d'eau, d'électricité, de gaz, d'assainissement ou de télécommunication. Jedná se sice o velmi dlouhý termín, ovšem s ohledem k výše uvedenému se jeví vhodnější než případný kalk réseau d'ingénieur, který nemá ve francouzských předpisech žádný lexikální základ. Ačkoli chybí právní definice, lze se domnívat, že se jedná o dokonalé ekvivalenty.

7. Klamavá reklama je podle NOZ (§2976) jedním z projevů nekalé soutěže. Nekalá soutěž je upravena rovněž ve francouzském právu. Např. Code de la consommation (art. L121-2 - art. L121-5) vymezuje termín pratiques commerciales trompeuses, který ovšem výrazně přesahuje koncept klamavé reklamy. Ve francouzském právu se lze také setkat s termíny publicité trompeuse 
(Code de l'environnement: art. L142-2) a publicité mensongère (Code de la procédure pénale: art. 2-17). V obou případech však tyto termíny postrádají legální definice. Při odhlédnutí od francouzského práva směrem k nadnárodnímu lze narazit na směrnici Evropské unie 84/450/CEE, která vymezuje právě tento koncept. Zatímco v české verzi dokumentu k tomu užívá termín klamavá reklama, ve francouzské verzi téhož právního předpisu je tento koncept označen jako publicité trompeuse. Jelikož Česká republika i Francie jsou členy Evropské unie a jako takové jsou vázané jejími právními přepisy, lze považovat koncepty označované respektive jako klamavá reklama a publicité trompeuse za dokonale ekvivalentní.

8. Kontrolní komise je v NOZ (§262-§264) definována jakožto kontrolní orgán spolku (§214). Při hledání vhodného překladu vzhledem k ekvivalentnosti právních konceptů je proto nejprve třeba zjistit, zda ve francouzském právu existuje koncept spolek. Slovníky jako překlad termínu spolek navrhují výraz association, který upravuje zákon „loi du 1er juillet 1901 relative au contrat d'association“. Jasně z něj však vyplývá, že association a spolek jsou jen částečně ekvivalentní. Rozdílnost konceptů mimo jiné spočívá v tom, že association nemá podle výše zmíněného zákonu žádný kontrolní orgán. Při zkoumání kontrolních orgánů existujících ve francouzském právu lze narazit na obecný termín organe de surveillance (Code de commerce: art. L210-8) a na název konkrétního kontrolního orgánu conseil de surveillance (Code de commerce: art. 225-68), který se užívá u francouzských právnických osob société anonyme či société à responsabilité limitée. Jelikož se zdá př́liš komplikované (a rovněž na hranici srozumitelnosti) vytvářet pro termín spolek ve francouzštině neologismus, který by ve francouzském právu neměl žádnou oporu, zdá se vhodnější využít výše zmíněných poznatků a navrhnout jako překlad kontrolní komise termín conseil de surveillance d'association, ačkoli association je pouze částečným ekvivalentem spolku a při užití tohoto termínu v překladu je třeba mít tuto skutečnost na paměti. Navrhovaný překlad spojuje dva ve francouzském právu již existující termíny a díky tomu se zdá srozumitelnější než případný zcela nově vytvořený neologismus, at už v podobě kalku či jiné.

9. Kupónový arch není v NOZ (§523) definován, nicméně jeho podstata vyplývá z kontextu daného ustanovení. Kupónový arch představuje soubor kupónů coby cenných papírů na doručitele, které se váží k právu na výnos z držení určitého cenného papíru a které obsahují stanovené náležitosti. Ve francouzském právu jsou cenné papíry upravené v Code de commerce a v tomto právním předpisu (a rovněž v Code général des impôts, annexe 2) se lze rovněž setkat s termínem coupon, který ovšem není zcela ekvivalentní k českému termínu kupón (např. coupon se vydává na jméno, nikoli na doručitele jako kupón). V právním předpisu „décret nº $48-1683$ du 30 octobre 1948 fixant certaines caractéristiques des valeurs mobilières" (art. 5) je zmíněn feuille de coupons, který se vydá v př́padě expirace data platnosti coupons. Tento termín také uvádí jeden ze slovníků (Dubský, Dubský, Vlasák 1998). Tento termín lze považovat za vhodný překlad kupónového archu, nicméně je třeba mít na paměti, že se nejedná o dokonalé ekvivalenty (viz pouze částečná ekvivalence coupon a kupón).

10. Kvitance je podle NOZ (§1949) potvrzení o splacení dluhu vydané věřitelem dlužníkovi. Vocabulaire juridique uvádí výraz quittance a k němu dvě definice. První odpovídá definici kvitance v NOZ, podle druhé se jedná o jakýkoli dokument potvrzující zaplacení. Užívání tohoto termínu ve francouzském právu odpovídá těmto dvěma definicím. V některých případech je vztah dlužníka a věřitele patrný z kontextu, v jiných nikoli. Lze tedy říct, že quittance je významově širší než kvitance (např. Code des assurances: art. R421-66). Jedná se proto o částečnou ekvivalenci. Přesto je možné považovat quittance za vhodný překlad pro kvitanci, pokud se bude brát zřetel právě na skutečnost, že se jedná o významově širší termín.

11. Rizika mimo kontrolu podnikatele spojená s poskytovanou finanční službou je jediným termínem v NOZ (§ 1843 odst. 1 písm. f), který obsahuje tři romanismy (riziko, kontrola, finanční). $\mathrm{V}$ př́íslušném ustanovení NOZ není tento termín definován a pro porozumění konceptu, který 
označuje, je třeba nejprve prozkoumat jednotlivé části tohoto výrazu. Finančni služby jsou upraveny v §1841 NOZ jako služby týkající se financí, mezi něž patří např́́klad bankovnictví nebo směna měn. Termín kontrola je upraven v zákonu o kontrole (zákon č. 255/2012 Sb., o kontrole (kontrolní řád), §2), ale zdá se, že ve zkoumaném kontextu se jedná spíše o jakousi možnost ovlivnění, než o kontrolu ve smyslu legální definice (tj. činnost kontrolních orgánů). Termín podnikatel je definován v §420-§422 NOZ. Výraz riziko legálně upraven není a jedná se o obecný výraz. Ve francouzském právu rovněž nelze najít definici konceptu rizika mimo kontrolu podnikatele spojená s poskytovanou finanční službou ani odpovídající francouzský termín. V Code de la consommation (art. R222-1, 2 ${ }^{\circ}$ ) ovšem existuje ustanovení, které svým obsahem přibližně odpovídá analyzovanému termínu včetně užité terminologie. ${ }^{4}$ Termín finanční služby je srovnatelný s užitým termínem service financier definovaném v Code monétaire et financier (Livre I, II, III, Livre V titre V). V daném kontextu odpovídá českému podnikatel francouzský termín fournisseur ve smyslu „poskytoval služby“, který se v tomto př́ípadě zdá vhodnější z důvodu jeho užití ve výše zmíněném ustanovení oproti termínu entrepreneur, který navrhují některé ze slovníků jako překlad termínu podnikatel. Výrazy risques (rizika) a influence (v tomto kontextu ekvivalent výrazu kontrola) jsou obecné a nemají legální definici. Vzhledem ke všem výše popsaným skutečnostem je navrhovaný překlad termínu rizika mimo kontrolu podnikatele spojená $s$ poskytovanou finančni službou neologismus utvořený podle terminologie z ustanovení Code de la consommation (art. R222-1, 20) a kopírující strukturu českého termínu. Podoba tohoto neologismu je následující: risques ininfluençables par le fournisseur liés aux services financiers fournis. Vzhledem ke zmíněnému ustanovení v Code de la consommation se lze domnívat, že český a francouzský termín označují tentýž koncept a jedná se tedy o dokonalé ekvivalenty.

12. Zákonný režim je definován v NOZ (§708-§728) je jeden ze tří režimů správy společného jmění manželů (spolu se smluveným režimem a režimem založeným rozhodnutím soudu, viz níže). $\mathrm{V}$ tomto př́padě se způsob správy řídí podmínkami stanovenými v NOZ (§709-§712). Ačkoli ve francouzském právu existují termíny régime légal a régime conventionnel, které zdánlivě svým lexikem odpovídají zákonnému režimu a smluvenému režimu, jedná se o zpo̊soby vypořádání společného jmění manželů $\mathrm{v}$ př́́padě rozvodu a nelze je tedy používat jako překlady režimů v českém právu. Francouzské právo pro způsoby správy společného jmění manželů používá termín communauté (Code civil: art. 1400 - art. 1491). V př́padě zákonného režimu by se jednalo o communauté légale. I ve francouzském právu se jedná o způsob správy podle podmínek stanovených zákonem a na první pohled by se tak jednalo o dokonalé koncepty. Tento dojem je však jen zdánlivý, nebot při bližším prozkoumání podmínek upravující zákonný režim a communauté légale je patrné, že některé z těchto podmínek se v příslušných právních předpisech liší (např. art. 1425 Code civil znemožňuje, aby jeden manžel pronajal pozemek nebo budovu pro komerční účely spadající pod společné jmění, přičemž zákonného režimu se žádné takové ustanovení netýká). Je tedy zřejmé, že se jedná o částečné ekvivalenty. Přrislušný termín se však jeví jako vhodný překlad, pokud bude brán zřetel na rozdílnost právních konceptů.

13. Smluvený režim je podle NOZ (§708-§728) jedním ze tří režimů, kterými lze řídit správu společného jmění manželi̊. Smluvený režim přitom představuje takový druh režimu, který je odlišný od zákonného režimu (viz výše) a zároveň se na jeho ustanoveních dohodnou sami manželé (na rozdíl od režimu založeného rozhodnutím soudu, viz níže). Ve francouzském právu se lze setkat s termínem communauté conventionnelle, jakožto se způsobem správy odlišným od communauté

\footnotetext{
${ }^{3}$ Srovnejte ovšem s definicí termínu přípustné riziko (trestní zákoník: §31).

${ }^{4}$ „Le cas échéant, le fournisseur précise au consommateur, d'une part, que le service financier est lié à des instruments qui impliquent des risques particuliers du fait de leurs spécificités ou des opérations à exécuter ou dont le prix dépend de fluctuations des marchés financiers sur lesquelles le fournisseur n'a aucune influence et, d'autre part, que les performances passées ne laissent pas présager des performances futures" (Code de la consommation, art. R222-1, $2^{\circ}$ ).
} 
légale (viz výše). Jelikož již bylo výše zmíněno, že podmínky správy společného jmění manželů se v zákonném režimu a v communauté légale liší, je zřejmé, že i smluvený režim a communauté conventionnelle jsou jen částečně ekvivalentní koncepty, nebot některá ustanovení spadající v českém právu pod zákonný režim už mohou spadat pod communauté conventionnelle a naopak. Při uvědomění si těchto rozdílů lze communauté conventionelle používat jako překlad smluveného režimu.

14. Režim založený rozhodnutím soudu je vedle smluveného režimu a zákonného režimu jedním ze tři možných režimů správy společného jmění manželi̊ podle NOZ (§708-§728). Z Code civil vyplývá, že tento typ režimu na rozdíl od zbývajících dvou typů režimu ve francouzském právu neexistuje. Jedná se tedy o bezekvivalentní koncept. Jako překlad lze navrhnout termín communauté par décision de la justice. Výraz communauté odpovídá konceptu režimu ve francouzštině (viz výše komentář ke smluvenému režimu a zákonnému režimu), výraz décision explicitně vyjadřuje vznik tohoto typu communauté rozhodnutím po vzoru českého termínu a nakonec justice vyjadřuje soudní orgány a zároveň předchází obtížím spjatým s odlišnými termíny pro soudy různých stupňů ve francouzském právu. Vytvořený neologismus communauté par décision de la justice by pak byl dokonalým ekvivalentem českého režim založený rozhodnutím soudu.

15. Srovnávací reklama je podobně jako výše zmíněná klamavá reklama jedním z projevů nekalé soutěže, jak uvádí NOZ (§2980). Podobně jako v př́padě klamavé reklamy je koncept srovnávací reklamy zakotven v evropském právu (směrnice 97/55/CE), kde je ve francouzské verzi tohoto dokumentu pojmenován publicité comparative. Na rozdíl od situace týkající se klamavé reklamy a jí odpovídajícímu překladu publicité trompeuse je publicité comparative blíže upravena také ve francouzském právu (Code de la consommation: art. L122-4 - L122-5), a to detailněji než v českém právu, například v oblasti použití tohoto typu reklamy nebo ohledně povinností jejího původce. Ovšem jelikož tato podrobná úprava není v rozporu s úpravou v NOZ a také vzhledem k tomu, že se jedná o koncept zakotvený v evropském právu, lze se domnívat, že termín publicité comparative je vhodným překladem pro termín srovnávací reklama a že se zároveň jedná o dokonale ekvivalentní termíny.

16. Svěrenský fond definuje NOZ (§1448-§1474) jako převedení části majetku do péče správce, od jehož vlastnictví bude tento majetek oddělený. Svěřenské fondy jsou zapsány v evidenci svěřenských fondů a mohou mít soukromý nebo veřejný účel, případně mohou být pořízeny pro případ smrti. Francouzské právo zavádí pojem fiducie (Code civil: art. 2011 - art. 2030). Jeho právní vymezení je v některých ohledech srovnatelné se svěřenským fondem (např. zápis do příslušné evidence nebo oddělení převedeného majetku od vlastnictví správce), ovšem v jiných se odlišuje (např. fiducie umožňuje na rozdíl od svěrenského fondu převést kromě majetku i práva). Je tedy patrné, že se jedná pouze o částečné ekvivalenty. Přesto se lze domnívat, že fiducie je vhodným překladem pro svěrenský fond, ovšem při překladu je třeba mít odlišnosti v právních konceptech na paměti.

\section{Analýza a syntéza výsledků překladu}

Výše byly popsány jednotlivé české termíny vybrané k překladu, byl analyzován jejich právní koncept, který se následně srovnal s obdobnými právními koncepty ve francouzském právu, a nakonec byl vybrán či vytvořen vhodný překlad těchto termínů z češtiny do francouzštiny s ohledem na právní koncepty. Tabulka 3 přehledně shrnuje výsledky překladu. 
Tabulka 3: Přehled navrhovaných termínů

\begin{tabular}{|c|c|c|}
\hline & vybraný termín obsahující romanismus/y & francouzský překlad \\
\hline 1. & diplomatická mise & une mission diplomatique \\
\hline 2. & dokumentární akreditiv & un crédit documentaire \\
\hline 3. & finanční záruka & un cautionnement financier \\
\hline 4. & invalidita & une invalidité \\
\hline 5. & investiční riziko & un risque afférent à l'investissement \\
\hline 6. & inženýrská sít & $\begin{array}{l}\text { des réseaux d'eau, d'électricité, de gaz, } \\
\text { d'assainissement ou de télécommunication }\end{array}$ \\
\hline 7. & klamavá reklama & une publicité trompeuse \\
\hline 8. & kontrolní komise & un conseil de surveillance d'association \\
\hline 9. & kupónový arch & une feuille de coupons \\
\hline 10. & kvitance & une quittance \\
\hline 11. & režim založený rozhodnutím soudu & une communauté établie par décision de la justice \\
\hline 12. & $\begin{array}{l}\text { rizika mimo kontrolu podnikatele spojená } \\
\text { s poskytovanou finanční službou }\end{array}$ & $\begin{array}{l}\text { des risques ininfluençables par le fournisseur liés } \\
\text { aux services financiers fournis }\end{array}$ \\
\hline 13. & smluvený režim & une communauté conventionnelle \\
\hline 14. & srovnávací reklama & une publicité comparative \\
\hline 15. & svěřenský fond & une fiducie \\
\hline 16. & zákonný režim & une communauté légale \\
\hline
\end{tabular}

Již výše bylo zmíněno, že při hledání odpovídajících termínů ve francouzském právu se postupovalo několika zpo̊soby. Zdá se, že pro překladatele je situace nejsnazší, jedná-li se o koncept zakotvený v nadnárodních právních dokumentech, kterými jsou vázány obě zkoumané země. Koncept diplomatická mise je zaveden v mezinárodní smlouvě. Jelikož tuto smlouvu přijaly Česká republika i Francie, jsou dané právní koncepty označované těmito termíny dokonale ekvivalentní. Pro nalezení vhodného francouzského překladu bylo dostačující prozkoumat verzi dané mezinárodní smlouvy ve francouzštině. Obdobná situace je v případě konceptů označovaných v češtině termíny srovnávací reklama a klamavá reklama. Ty jsou zakotveny v evropském právu. Tím jsou vázány Francie i Česká republika a tak jsou tyto právní koncepty i v těchto př́padech dokonale ekvivalentní. Jelikož jednotlivé právní předpisy evropského práva jsou vyhotoveny ve všech oficiálních jazycích Evropské unie (tedy včetně češtiny a francouzštiny), stačí vyhledat příslušné právní předpisy v těchto jazycích a v nich dané termíny.

V př́ípadě absence právní předpisu přesahujícího rámec národního práva je třeba zaměřit se na právní předpisy vlastní jednotlivým zemím. Tato situace se týkala většiny termínů, které byly vybrány pro překlad. U některých z nich se v českém a francouzském právu nacházel shodný právní koncept, a jednalo se tedy o dokonalé ekvivalenty (např. inženýrská sít), u jiných byla ekvivalence konceptů jen částečná, nebot se právní úprava daných konceptů v některých ohledech lišila. Ve většině případů se však zdá, že pokud odlišnosti nejsou př́liš velké, může se pro překlad použít zavedený termín, i když označuje jen částečně ekvivalentní koncept. Jednotlivé rozdílnosti konceptů je však třeba mít při překladu na paměti, zejména vzhledem k typu překládaného textu a k jeho cílovému čtenáři. Zatímco pro laickou veřejnost bude důležitější pochopení celkového sdělení textu oproti drobným odlišnostem právních konceptů, pro odborníky mohou mít právě tyto detaily kritickou důležitost.

Ve dvou případech neměly české právní termíny ve francouzském právu žádný protějšek. V této situaci bylo třeba přikročit k vytvoření neologismu. Vztahy mezi českými a francouzskými právními koncepty zachycuje Tabulka 4. 
Tabulka 4: Přehled ekvivalence konceptů

\begin{tabular}{|c|c|c|}
\hline & vybraný výraz & $\begin{array}{l}\text { ekvivalent ve } \\
\text { francouzském právu }\end{array}$ \\
\hline 1. & diplomatická mise & dokonalý \\
\hline 2. & dokumentární akreditiv & dokonalý \\
\hline 3. & finanční záruka & částečný \\
\hline 4. & invalidita & částečný \\
\hline 5. & investiční riziko & dokonalý \\
\hline 6. & inženýrská sít & dokonalý \\
\hline 7. & klamavá reklama & dokonalý \\
\hline 8. & kontrolní komise & nulový \\
\hline 9. & kupónový arch & částečný \\
\hline 10. & kvitance & částečný \\
\hline 11. & režim založený rozhodnutím soudu & nulový \\
\hline 12. & rizika mimo kontrolu podnikatele spojená s poskytovanou finanční službou & dokonalý \\
\hline 13. & smluvený režim & částečný \\
\hline 14. & srovnávací reklama & dokonalý \\
\hline 15. & svěřenský fond & částečný \\
\hline 16. & zákonný režim & částečný \\
\hline
\end{tabular}

V rozporu s očekávanými výsledky byly mezi 16 zkoumanými právními koncepty dva nulově ekvivalentní koncepty (kontrolní komise, režim založený rozhodnutím soudu), sedm částečně ekvivalentních konceptů (finanční záruka, invalidita, kupónový arch, kvitance, smluvený režim, svěrenský fond, zákonný režim) a sedm dokonale ekvivalentní konceptů (diplomatická mise, dokumentární akreditiv, investiční riziko, inženýrská sít, klamavá reklama, rizika mimo kontrolu podnikatele spojená s poskytovanou finanční službou, srovnávací reklama).

Většina termínů vybraných $\mathrm{k}$ překladu obsahovala galicismy (s výjimkou tří italianismů investiční, riziko, rizika), a jelikož se jednalo o překlad do francouzštiny, není bez zajímavosti otázka, zda se tato slova francouzského původu vyskytují i v odpovídajících francouzských termínech. To zachycuje Tabulka 5, v níž jsou galicismy a jejich případné zachování ve francouzském překladu vyznačeny tučným písmem.

Tabulka 5: Zachování zkoumaných romanismů při překladu

\begin{tabular}{cll}
\hline & vybraný výraz & francouzský překlad \\
\hline 1. & diplomatická mise & une mission diplomatique \\
2. & dokumentární akreditiv & un $\underline{\text { crédit documentaire }}$ \\
3. & finanční záruka & un cautionnement financier \\
4. & invalidita & une invalidité \\
5. & investiční riziko & un risque afférent à l'investissement \\
6. & inženýrská sít & des réseaux d'eau, d'électricité, de gaz, \\
& & d'assainissement ou de télécommunication \\
7. & klamavá reklama & une publicité trompeuse \\
8. & kontrolní komise & un conseil de surveillance d'association \\
9. & kupónový arch & une feuille de coupons \\
10. & kvitance & une quittance \\
11. & režim založený rozhodnutím soudu & une communauté établie par décision de la justice
\end{tabular}


12. rizika mimo kontrolu podnikatele spojená s poskytovanou finanční službou

13. smluvený režim

14. Srovnávací reklama

15. svěřenský fond

16. zákonný režim des risques ininfluençables par le fournisseur liés aux services financiers fournis

une communauté conventionnelle

une publicité comparative

une fiducie

une communauté légale

Jak je z tabulky patrné, z celkového počtu 19 romanismů se při překladu zachovalo pouze 9 (budeme-li počítat italianismus crédit v termínu crédit documentaire, ačkoli v českém termínu se jedná o galicismus akreditiv, pak 10). Za zmínku stojí, že italianismy se při překladu zachovaly všechny tři.

Je samozřejmě možné se ptát, proč se galicismy zachovaly v překladu do francouzštiny v relativně omezené míře, ovšem na tuto otázku nelze odpovědět s jistotou. Lze se jen dohadovat, že autoři daných právních předpisů v českém a francouzském právu měli odlišné názory na to, jaké lexikum by k jejich označení bylo nejvhodnější. Vzniklé termíny mohly být vytvořeny nezávisle na sobě a tím pádem mají nejednotné lexikum. V úvahu lze také vzít časovou diskrepanci mezi okamžikem vypůjčení romanismu a vznikem daného právního konceptu. Daný romanismus tedy mohl být v době vzniku daného právního konceptu již v českém právu zavedený, případně prošel procesem adaptace do té míry, že ho autoři NOZ nepovažovali za cizí slovo, které by odpovídalo definici v Legislativních pravidlech vlády (Vláda ČR 2018).

\section{Srovnání navržených překladů s oficiálním překladem občanského zákoníku}

Na webových stránkách Ministerstva spravedlnosti České republiky je dostupný oficiální překlad vybraných českých právních pramenů včetně občanského zákoníku. K dispozici jsou překlady do angličtiny, francouzštiny, němčiny a ruštiny. Tabulka 6 zachycuje vybraný český termín, francouzské překlady navrhované v rámci této studie (dále jen NFP) a nakonec překlady z oficiálního překladu (dále jen POP). V následující části této studie dojde ke srovnání NFP a POP a k posouzení vhodnosti POP jako překladů daných českých termínů s ohledem na ekvivalenci konceptů a respektování existující francouzské terminologie.

Tabulka 6: Srovnání navrhovaných a oficiálních prekladů vybraných termínů

\begin{tabular}{|c|c|c|c|}
\hline & $\begin{array}{l}\text { vybraný termín obsahující } \\
\text { romanismus /y }\end{array}$ & $\begin{array}{l}\text { navrhovaný francouzský } \\
\text { překlad }\end{array}$ & oficiální překlad NOZ \\
\hline 1. & diplomatická mise & une mission diplomatique & une mission diplomatique \\
\hline 2. & dokumentární akreditiv & un crédit documentaire & un accréditif documentaire \\
\hline 3. & finanční záruka & un cautionnement financier & une garantie financière \\
\hline 4. & invalidita & une invalidité & une invalidité \\
\hline 5. & investiční riziko & $\begin{array}{l}\text { un risque afférent } \\
\text { à l'investissement }\end{array}$ & un risque d'investissement \\
\hline 6. & inženýrská sít & $\begin{array}{l}\text { des réseaux d'eau, d'électricité, } \\
\text { de gaz, d'assainissement ou de } \\
\text { télécommunication }\end{array}$ & un réseau d'ingénierie \\
\hline 7. & klamavá reklama & une publicité trompeuse & une publicité mensongère \\
\hline 8. & kontrolní komise & $\begin{array}{l}\text { un conseil de surveillance } \\
\text { d'association }\end{array}$ & un comité de contrôle \\
\hline 9. & kupónový arch & une feuille de coupons & une feuille de coupon \\
\hline 10. & kvitance & une quittance & une quittance \\
\hline
\end{tabular}


11. režim založený rozhodnutím soudu une communauté établie par décision de la justice

12. rizika mimo kontrolu podnikatele spojená s poskytovanou finanční službou

13. smluvený režim

14. srovnávací reklama

15. svěřenský fond

16. zákonný režim des risques ininfluençables par le fournisseur liés aux services financiers fournis une communauté conventionnelle une publicité comparative une fiducie une communauté légale un régime établi par un arrêté du tribunal

des risques liés à la fourniture de services financiers qui échappent au contrôle du professionnel un régime convenu une publicité comparative un fonds de fiducie une régime juridique

Ze srovnání obou skupin překladů je zřejmé, že se dokonale shodují jen ve čtyřech př́ípadech. Těmi jsou diplomatická mise (mission diplomatique), invalidita (invalidité), kvitance (quittance) a srovnávací reklama (publicité comparative). Jelikož v těchto případech POP odpovídají NFP, lze je vzhledem $\mathrm{k}$ výše uvedené argumentaci pro jednotlivé NFP považovat za vhodné překlady daných českých termínů.

Ve třech dalších případech (investiční riziko, dokumentární akreditiv, kupónový arch) se POP od NFP sice liší, ovšem vzhledem k míře odlišnosti se lze domnívat, že POP jsou v těchto př́ipadech dobře srozumitelné a lze je bez větších obtíží použít jako překlady českých termínů: Jak risque afférent à l'investissement, tak i risque d'investissement je možné nalézt v textech francouzských právních předpisů a způsob tvorby těchto kompozit je nejspíše jen stylistickou nuancí.

Termíny crédit documentaire i accréditif documentaire se řadí mezi překlady dokumentárního akreditivu nabízené ve slovnících včetně výkladového slovníku Vocabulaire juridique (v němž heslo accréditif documentaire př́mo odkazuje $\mathrm{k}$ heslu crédit documentaire), proto se lze domnívat, že oba překlady jsou akceptovatelné.

$\mathrm{V}$ př́padě kupónového archu se oba překlady liší pouze použitím plurálu (NFP), respektive singuláru (POP) u termínu coupon. Není zřejmé, jaký důvod vedl překladatele POP k použití jednotného čísla, nicméně ve francouzských právních pramenech ${ }^{5}$ se vyskytuje pouze termín feuille de coupons, tedy s použitím plurálu, proto se zdá, že se jedná o vhodnější překlad, byt feuille de coupon by nejspíš rovněž byl srozumitelný.

$\mathrm{V}$ dalších pěti případech se lze domnívat, že POP by zřejmě byly srozumitelné, ovšem je možné k nim vznést určité výhrady, nebot je možné, že by při jejich užití mohlo dojít k určitým významovým posunům. Jedná se o překlady termínů finanční záruka, klamavá reklama, svěrenský fond, rizika mimo kontrolu podnikatele spojená s poskytovanou finanční službou a kontrolní komise.

$\mathrm{V}$ případě finanční záruky použitý POP (garantie financière) ve francouzském právu existuje, a to ve smyslu záruky či záruční lhůty. Při srovnání konceptů ovšem finanční záruce odpovídá spíše výraz cautionnement, který je v NFP doplněn adjektivem financier pro jeho zpřesnění a odlišení od jednoslovného termínu cautionnement, nebot cautionnement podle ustanovení Code civil přesahuje svým významem koncept finanční záruky. Výsledný termín NFP cautionnement financier je tedy neologismus, ovšem snaží se respektovat již existující francouzskou terminologii, proto se lze domnívat, že se jedná o vhodnější překlad než garantie financière.

Za zmínku stojí rovněž slovní spojení publicité mensogère (POP) a jeho protějšek publicité trompeuse (NFP), která jsou sice obě navrhovaná některými slovníky a lze je nalézt i ve francouzských právních předpisech, ovšem bez definice. Pro publicité trompeuse však definici poskytují prameny práva Evropské unie ${ }^{6}$ (a to způsobem shodným s definicí klamavé reklamy v NOZ). Proto se termín publicité trompeuse jeví jako vhodnější překlad než publicité mensongère, ačkoli druhý jmenovaný překlad by patrně byl srozumitelný.

\footnotetext{
${ }^{5}$ Viz décret $\mathrm{n}^{\circ}$ 48-1683 du 30 octobre 1948 fixant certaines caractéristiques des valeurs mobilières.

${ }^{6}$ Viz directive 84/450/CEE du Conseil du 10 septembre 1984 relative au rapprochement des dispositions législatives, réglementaires et administratives des États membres en matière de publicité trompeuse.
} 
$\mathrm{V}$ př́padě svěrenského fondu, respektive jeho překladu fonds de fiducie sice byl použit termín fiducie (což je NFP a definice fiducie ve francouzském právu částečně odpovídá definici svěrenského fondu v NOZ), ovšem kompozitum fonds de fiducie nemá ve francouzských právních pramenech oporu (vždy se hovoří pouze o fiducie), proto se lze domnívat, že jednoslovný překlad fiducie je vhodnější.

Podobně ani termín comité de contrôle nemá žádné zakotvení ve francouzských právních předpisech. Kontrolní orgány u jistých typů právnických osob se ve francouzské terminologii nazývají termínem conseil de surveillance, přičemž association (částečný ekvivalent spolku, k němuž se kontrolní komise váže) žádný kontrolní orgán stanovený nemá. Jak v př́ípadě POP (comité de contrôle), tak v př́padě NFP (conseil de surveillance d'association) se jedná o neologismy, nicméně NFP využívá již existujících francouzských termínů. Proto se lze domnívat, že termín conseil de surveillance d'association je srozumitelnější než termín comité de contrôle.

Termín risques liés à la fourniture de services financiers qui échappent au contrôle du professionnel jakožto překlad českého termínu rizika mimo kontrolu podnikatele spojená s poskytovanou finanční službou je relativně srozumitelný, nicméně nerespektuje terminologii užitou ve francouzských právních předpisech. Byt ve francouzských právních pramenech neexistuje pro tento koncept termín, je v nich tento koncept opsán ${ }^{7}$ a z textu daného ustanovení je možné extrahovat odpovídající lexikum. Termín POP je navíc polovětnou konstrukcí, nikoli nominálním syntagmatem jako český termín. Z těchto důvodů lze vyjádřit názor, že NFP risques ininfluençables par le fournisseur liés aux services financiers fournis je vhodnější, nebot kopíruje morfologickou strukturu českého termínu a zároveň využívá francouzské termíny mající oporu ve francouzských právních předpisech v souvislosti s tímto konceptem.

Zbývající čtyři POP termíny nejenže se od NFP značně liší, ale rovněž se lze domnívat, že jejich používání by mohlo mít závažné dopady v podobě významových posunů, chybných interpretací, či dokonce nesrozumitelnosti. Jedná se o překlady termínů inženýrská sít, zákonný režim, smluvený režim a režim založený rozhodnutím soudu.

Ačkoli termíny réseau a ingénierie (tedy prvky POP réseau d'ingénierie) ve francouzském právu existují, lze je nalézti jen odděleně, a nikoli jako kompozitum pro pojmenování konceptu inženýrské sitě. Zatímco český termín inženýrská sít označuje vodovodní, energetické, kanalizační nebo jiné druhy vedení, výraz ingénierie je používán spíše ve smyslu technických či konstrukčních řešení. Lze se proto domnívat, že slovní spojení réseau d’ingénierie by bylo obtížně srozumitelné. Pro koncept, který v českém právu označuje termín inženýrská sít, neexistuje ve francouzském jednotný termín, spíše se jedná o výčet různých druhů vedení. Proto se navrhovaný termín réseaux d'eau, d'électricité, de gaz, d'assainissement ou de télécommunication zdá srozumitelnější a vhodnější navzdory své délce.

Největší významový posun mezi POP nastává u překladů termínů zákonný režim, smluvený režim a režim založený rozhodnutím soudu. Problematický je použitý termín régime, který je obsažen ve všech třech překladech. Ve francouzském právu sice existují termíny régime légal a régime conventionnel, které zdánlivě odpovídají (alespoň co do použitého lexika) termínům zákonný režim a smluvený režim, ovšem na rozdíl od českých termínů, které upravují druhy správy společného jmění manželů za trvání manželství, tyto francouzské termíny označují způsoby rozdělení společného jmění v případě rozvodu. Ani rozvíjející adjektiva neodpovídají zvyklostem ve francouzském právu (POP obsahuje participium convenu místo adjektiva conventionnel a adjektivum juridique namísto légal). Ve francouzském právu přitom existují termíny communauté légale a communauté conventionnelle, které upravují dva způsoby správy společného jmění manželů, z nichž první jmenovaný je v souladu s ustanoveními zákona a druhý jmenovaný odpovídá správě podle dohody manželi̊ a odlišně od zákona (při komparaci s českými koncepty smluvený režim

\footnotetext{
$\overline{{ }^{7} \text { Viz Code de la consommation: art. R222-1, }}{ }^{\mathrm{o}}$.
} 
a zákonný režim se však jedná jen o částečnou ekvivalenci). Francouzské právo nezná koncept režimu založeného rozhodnutím soudu a navrhovaný termín jak v NFP, tak v POP je tedy neologismus. $\mathrm{V}$ případě $\mathrm{POP}$ je zde ovšem znovu problematické použití termínu régime, zatímco NFP volí po vzoru existujících francouzských termínů pro druhy správy společného jmění termín communauté. Lze se domnívat, že určité obtíže představuje i termín tribunal v POP, nebot tribunal označuje pouze prvoinstanční soud a tím pádem vylučuje ustanovení takového režimu správy společného jmění například prostřednictvím rozhodnutí v odvolacím řízení. NFP namísto toho operuje s neutrálním termínem justice.

Při srovnání POP a českých termínů se zdá, že zatímco termíny NFP se snažily vycházet z ekvivalence konceptů a již existující francouzské terminologie, v př́ípadě POP se jedná spíše o kalky, které přikládají důležitost zejména stejné nebo podobné lexikální struktuře termínů. Ačkoli v některých případech tento postup přinesl dobré výsledky, $\mathrm{v}$ jiných se takto vytvořené termíny pohybují na hranici srozumitelnosti nebo mají za následek různou míru zkreslení významu (zejména s ohledem na existující francouzskou právní terminologii). Z těchto důvodů nelze při překladu právních textů doporučit používání překladů termínů z oficiálního překladu NOZ.

\section{Závěr}

V této studii bylo prokázáno, že čeština stejně jako téměř všechny existující jazyky prošla procesem přejímání slov. Z poznatků získaných při výše popsaném výzkumu vyplynulo, že do češtiny pronikly nejen romanismy (tedy přjímky z románských jazyků), na něž se tento výzkum zaměřoval, ale i slova pocházející z dalších jazyků jako jsou angličtina, latina, řečtina a dalších. Lze je nalézt nejen v obecném jazyce, ale i v jazyce odborném. Tato studie potvrdila jejich př́tomnost v právní terminologii českého občanského zákoníku. Celkem bylo nalezeno 32 různých romanismů, z nichž 23 bylo francouzského původu a 9 italského původu. Přejímky z dalších románských jazyků se v korpusu občanského zákoníku nevyskytují. Romanismy byly součástí 129 různých lexikálních jednotek (jednoslovných i syntagmat). Některé romanismy se v korpusu vyskytují pouze jedinkrát, jiné se objevují opakovaně, v rámci různých lexikálních jednotek a v různých derivovaných formách.

Vybrané právní termíny obsahující romanismy (převážně galicismy) byly ve druhé části práce, která se zaměřovala na problematiku překladu právních termínů, přeloženy do francouzštiny. Překladu samotnému předcházela podrobná analýza právních konceptů označovaných vybranými termíny a jejich komparace s právními koncepty ve francouzském právu. Z celkového počtu 16 překládaných termínů se 7 týkalo dokonale ekvivalentních konceptů, 7 částečně ekvivalentních konceptů a 2 nulově ekvivalentních konceptů, tedy takových, které jsou francouzskému právu neznámé. Při komparaci ekvivalence konceptů se vycházelo především z francouzských primárních i sekundárních právních pramenů, v menší míře pak z pramenů mezinárodního práva a práva Evropské unie. Zatímco v některých případech (zejména u dokonale a některých částečně ekvivalentních konceptů) bylo možno pro výsledný překlad použít již zavedenou francouzskou terminologii, $\mathrm{v}$ případě nulové ekvivalence, a rovněž v dalších případech, $\mathrm{v}$ nichž to situace vyžadovala, bylo nutno přistoupit $\mathrm{k}$ tvorbě neologismu. Při volbě vhodného překladu byl zvláštní důraz kladen na ekvivalenci konceptů, ovšem v úvahu byly brány rovněž zavedený úzus a existující terminologie ve francouzských právních předpisech a také srozumitelnost pro potenciálního uživatele. Výsledné překlady jednotlivých termínů jsou součástí této studie a lze se domnívat, že by bylo možné je použít př̀i překladu právního textu.

Během procesu překladu bylo nutné vypořádat se s rozličnými obtížemi, na něž může překladatel právního textu při př̀ekladu narazit (např. nulová ekvivalence, částečná ekvivalence, tvorba neologismů, existence konceptu bez ustáleného termínu, pluralita možných překladů jednoho ter- 
mínu, absence definice konceptu a další), přičemž způsob jejich řešení je uveden v argumentaci, již lze nalézt u každého termínu překládaného v této studii. Způsob řešení těchto problémů může být inspirací pro další překladatele, jedná se však o řešení konkrétních situací, nikoli o univerzálně platná pravidla.

Součástí této studie bylo rovněž porovnání výsledných překladů s překlady totožných termínů v oficiálním překladu občanského zákoníku do francouzštiny a zhodnocení vhodnosti druhých zmíněných. $\mathrm{V}$ některých případech jsou překlady totožné, v jiných se mírně liší, ačkoli tato míra odlišnosti by neměla mít vliv na porozumění. V oficiálním překladu se ale lze setkat také s takovými překlady, jejichž užití by mohlo mít za následek výrazný významový posun či nesrozumitelnost. Zdá se, že důvodem nevhodných překladů je doslovný (kalkový) překlad termínů, aniž by byla brána v úvahu existující francouzská právní terminologie. Vzhledem k velikosti analyzovaného vzorku nelze zjištěná fakta vztáhnout na celý oficiální překlad občanského zákoníku do francouzštiny, ale zároveň je třeba zvážit, že i v takto malém vzorku byly nalezeny překlady, které mají za následek takovou míru zkreslení. S ohledem na zjištěná fakta proto v této chvíli nelze doporučit, aby překladatelé či jiní potenciální uživatelé využívali oficiální překlad občanského zákoníku do francouzštiny jako databázi překladů právních termínů z oblasti občanského práva.

Podrobnější analýza oficiálního překladu občanského zákoníku do francouzštiny co do vhodnosti překladu jednotlivých termínů by mohl být jeden z potenciálních směrů výzkumu v této oblasti, nebot by mohla přinést ucelenější představu o kvalitě překladu s ohledem na existující francouzskou terminologii a na potenciální využití oficiálního překladu při překládání právních dokumentů. Jako další možný směr bádání ohledně propojení romanismů (či obecně přejatých slov) a právní terminologie se nabízí zkoumání přítomnosti romanismů v dalších právních předpisech České republiky (např. trestní zákoník, zákon o obchodních korporacích a další), což by mohlo vést k poznání, zda je četnost romanismů v jednotlivých předpisech srovnatelná, nebo zda naopak mají některé oblasti práva větší tendenci k přejímání slov než jiné. Informace ohledně politiky otevřenosti vůči přejímkám z cizích jazyků by mohly být získány z komparace výskytu romanismů v rámci jednoho právního předpisu v průběhu let či z komparace českých právních předpisů a předpisů jiné země, např́klad Slovenska. Možné by bylo zkoumat také původ právních konceptů, nebot to by vedlo k poznání, zda dochází k přejímkám z románských jazyků jen na úrovni lexikální, nebo i sémantické.

\section{Financování}

Tato studie vznikla s podporou Grantové agentury Jihočeské univerzity 126/2019/H - Využití komputačních nástrojů při analýze diskurzu.

\section{Bibliografie}

Blatná, R. 2000. „K procesu přejímání slov.“ Pp 85-99 in Z. Hladká, P. Karlík. Čeština - univerzália a specifika 2: sbornik konference ve Šlapanicích u Brna 17.-19. 11. 1999. Brno: Masarykova univerzita.

Centre National des Ressources Textuelles et Lexicales. nedat. [online] Centre National des Ressources Textuelles et Lexicales [cit. 1. 1. 2018]. Dostupné z: http://www.cnrtl.fr/etymologie/.

Code civil. [online] Légifrance [cit. 1. 1. 2018]. Dostupné z: https://www.legifrance.gouv.fr/affichCode.do? cidTexte=LEGITEXT000006070721\&dateTexte $=20180216$.

Code de commerce. [online] Légifrance [cit. 1. 1. 2018]. Dostupné z: https://www.legifrance.gouv.fr/ affichCode.do?cidTexte=LEGITEXT000005634379\&dateTexte $=20180216$.

Code de la consommation. [online] Légifrance [cit. 1. 1. 2018]. Dostupné z: https://www.legifrance.gouv.fr/ affichCode.do?cidTexte=LEGITEXT000006069565\&dateTexte $=20180216$. 
Code de la construction et de l'habitation. [online] Légifrance [cit. 1. 1. 2018]. Dostupné z: https:// www.legifrance.gouv.fr/affichCode.do?cidTexte=LEGITEXT000006074096\&dateTexte $=20180216$.

Code de la sécurité sociale. [online] Légifrance [cit. 1. 1. 2018]. Dostupné z: https://www.legifrance.gouv.fr/ affichCode.do?cidTexte=LEGITEXT000006073189\&dateTexte $=20180216$.

Code de l'environnement. [online] Légifrance [cit. 1. 1. 2018]. Dostupné z: https://www.legifrance.gouv.fr/ affichCode.do?cidTexte=LEGITEXT000006074220\&dateTexte $=20180216$.

Code de l'urbanisme. [online] Légifrance [cit. 1. 1. 2018]. Dostupné z: https://www.legifrance.gouv.fr/ affichCode.do?cidTexte=LEGITEXT000006074075\&dateTexte $=20180216$.

Code de procédure pénale. [online] Légifrance [cit. 1. 1. 2018]. Dostupné z: https://www.legifrance.gouv.fr/ affichCode.do?cidTexte=LEGITEXT000006071154\&dateTexte $=20180216$.

Code des assurances. [online] Légifrance [cit. 1. 1. 2018]. Dostupné z: https://www.legifrance.gouv.fr/ affichCode.do?cidTexte=LEGITEXT000006073984\&dateTexte $=20180216$.

Code général des impôts, annexe 2. [online] Légifrance [cit. 1. 1. 2018]. Dostupné z: https:// www.legifrance.gouv.fr/affichCode.do?cidTexte=LEGITEXT000006069569\&dateTexte $=20180216$.

Code monétaire et financier. [online] Légifrance [cit. 1. 1. 2018]. Dostupné z: https:// www.legifrance.gouv.fr/affichCode.do?cidTexte=LEGITEXT000006072026\&dateTexte $=20180216$.

Convention de Vienne sur les relations diplomatiques. [online] United Nations, Office of Legal Affairs [cit. 1. 1. 2018]. Dostupné z: https://legal.un.org/ilc/texts/instruments/french/conventions/9_1_1961.pdf.

Cornu, G. 2005. Linguistique juridique. 3e éd. Paris: Montchrestien

Cornu, G. 2008. Vocabulaire juridique. 8e éd. Paris: Quadrige.

Čechová, M., M. Dokulil, Z. Hlavsa, J. Hrbáček, Z. Hrušková. 2000. Čeština - ̌reč a jazyk. 2. vyd. Praha: ISV nakladatelství.

Černý, J. 1998. Úvod do studia jazyka. Olomouc: Rubico.

Daneš, F. 2009. Kultura a struktura českého jazyka. Praha: Nakladatelství Karolinum.

Darbelnet, J., J.-P. Vinay. 1977. Stylistique comparée du français et de l'anglais: methode de traduction. Paris: Didier.

Décret du 3 juillet 1996 relatif à l'enrichissement de la langue française. [online] Légifrance [cit. 1. 1. 2018]. Dostupné z: https://www.legifrance.gouv.fr/affichTexte.do?cidTexte=JORFTEXT000000378502.

Décret $\mathrm{n}^{\circ} 48-1683$ du 30 octobre 1948 fixant certaines caractéristiques des valeurs mobilières. [online] Légifrance [cit. 1. 1. 2018]. Dostupné z: https://www.legifrance.gouv.fr/affichTexte.do?cidTexte= LEGITEXT000006070049\&dateTexte $=20171027$.

Directive 84/450/CEE du Conseil du 10 septembre 1984 relative au rapprochement des dispositions législatives, réglementaires et administratives des États membres en matière de publicité trompeuse. [online] EUR-LEX [cit. 1. 1. 2018]. Dostupné z: https://eur-lex.europa.eu/legal-content/FR/TXT/?uri=celex\% 3A31984L0450.

Directive 97/55/CE du Parlement Européen et du Conseil du 6 octobre 1997 modifiant la directive 84/450/CEE sur la publicité trompeuse afin d'y inclure la publicité comparative. [online] EUR-LEX [cit. 1. 1. 2018]. Dostupné z: https://eur-lex.europa.eu/legal-content/fr/TXT/?uri=CELEX\% 3A31997L0055.

Dubský, J., O. Dubský, V. Vlasák. 1998. Francouzsko-český a česko-francouzský obchodní slovník. Praha: Státní pedagogické nakladatelství.

Hauser, P. 1980. Nauka o slovní zásobě. Praha: Státní pedagogické nakladatelství.

Hodková, K. 2018. Romanismy v terminologii Nového občanského zákoníku a jejich francouzské ekvivalenty. České Budějovice: Jihočeská univerzita v Českých Budějovicích.

Holub, J., F. Kopečný. 1952. Etymologický slovnik jazyka českého. 3. vyd. Praha: Státní nakladatelství učebnic.

Jakobson, R. 1959. „On Linguistic Aspects of Translation.“ Pp 232-239 in R. A. Brower. On translation. Cambridge: Harvard University Press.

Karlík, P., M. Nekula, Z. Rusínová. 2003. Příruční mluvnice češtiny. 2. vyd. Praha: Nakladatelství Lidové noviny.

Kozmová, J., P. Brouland. 2013. Obchodní francouzština = Français commercial. 2. vyd. Brno: Edika.

Larišová, M. 2008. Francouzsko-český, česko-francouzský právnický slovnik. Plzeň: Vydavatelství a nakladatelství Aleš Čeněk.

Le Docte, E. 1997. Čtyřjazyčný právnický slovnik = Dictionnaire de termes juridiques en quatre langues $=$ Legal dictionary in four languages $=$ Rechtswörterbuch in vier Sprachen. Praha: CODEX. 
Légifrance.fr. 2018. Dostupné z: https://www.legifrance.gouv.fr/.

Loi du 1er juillet 1901 relative au contrat d'association. [online] Légifrance [cit. 1. 1. 2018]. Dostupné z: https://www.legifrance.gouv.fr/affichTexte.do?cidTexte=LEGITEXT000006069570.

Loi no 94-665 du 4 août 1994 relative à l'emploi de la langue française. [online] Légifrance [cit. 1. 1. 2018]. Dostupné z: https://www.legifrance.gouv.fr/affichTexte.do?cidTexte=JORFTEXT000000349929\& dateTexte $=20180216$.

Machek, V. 1968. Etymologický slovník jazyka českého. 2. vyd. Praha: Academia.

Nařízení č. 1 o užívání jazyků v Evropském hospodářském společenství. 6. 10. 1958. In: Úřední věstník Evropské unie, svazek 17. [online] Úřad pro publikace Evropské unie [cit. 1. 1. 2018]. Dostupné z: https://op.europa.eu/cs/publication-detail/-/publication/115852e8-30ac-496e-8015-d580366ff059/ language-cs.

Občanský zákoník, oficiální překlad do francouzštiny. [online] Nový občanský zákoník [cit. 6. 7. 2019]. Dostupné z: http://obcanskyzakonik.justice.cz/index.php/home/zakony-a-stanoviska/preklady.

Online Etymology Dictionary. nedat. [online] Online Etymology Dictionary [cit. 1. 1. 2018]. Dostupné z: https://www.etymonline.com/.

Nečas, P., J. Pospíšil. 2012. „Důvodová zpráva k Novému občanskému zákoníku.“ [online] Ministerstvo spravedlnosti [cit. 12. 2. 2019]. Dostupné z: http://obcanskyzakonik.justice.cz/images/pdf/Duvodovazprava-NOZ-konsolidovana-verze.pdf.

Pataki, P. 1997. Česko-francouzský odborný slovník z oblasti právní, správní a politické = Dictionnaire juridique, administratif et politique tcheque-français (Variant.). Praha: Linde.

Pešek, O. 2017. „Galicismy v českém lexiku.“ Pp 561-565 in P. Karlík, M. Nekula, J. Pleskalová (eds.). Nový encyklopedický slovník češtiny. Praha: Nakladatelství Lidové noviny.

Petrů, I. 2015. „Codification de la terminologie juridique dans les définitions légales.“ Echo des études romanes 11 (1): 125-135.

Radimský, J. 2004. „Dans quelle mesure est-il possible de traduire un terme juridique?" Etudes romanes de Brno, Sborník prací FF MU L 25: 37-44.

Radimský, J. 2008. „La version tchèque du terme juridique européen: de quels critères disposons-nous pour juger de son adéquation?" Études romanes de Brno, Sbornik prací FF MU L 29: 87-97.

Radimský, J. 2017a. „Italianismy v českém lexiku. “ Pp 713-718 in P. Karlík, M. Nekula, J. Pleskalová (eds.). Nový encyklopedický slovnik češtiny. Praha: Nakladatelství Lidové noviny.

Radimský, J. 2017b. „Romanismy v českém lexiku.“ Pp 1564-1565 in P. Karlík, M. Nekula, J. Pleskalová (eds.). Nový encyklopedický slovnik češtiny. Praha: Nakladatelství Lidové noviny.

Rejzek, J. 2015. Český etymologický slovnik. 3. vyd. Praha: Leda.

Skalička, V. 2004. „Typ češtiny.“ Pp 475-536 in Vladimír Skalička: souborné dílo. II. díl, (1951-1963). Praha: Karolinum.

Smlouva o Evropské unii (konsolidované znění). 2012. In Úřední věstník Evropské unie, svazek 55. [online] EUR-LEX [cit. 1. 1. 2018]. Dostupné z: https://eur-lex.europa.eu/resource.html?uri=cellar:2bf140bfa3f8-4ab2-b506-fd71826e6da6.0008.02/DOC_1\&format=PDF.

Svobodová, D. 2007. Internacionalizace současné české slovní zásoby. Ostrava: Ostravská univerzita.

Svobodová, D. 2009. Aspekty hodnocení cizojazyčných přejímek: mezi módností a standardem. Ostrava: Ostravská univerzita v Ostravě, Pedagogická fakulta.

Šmilauer, V. 1972. Nauka o českém jazyku. Praha: Státní pedagogické nakladatelství.

Tionová, A. 1992. Francouzština pro pokročilé. 1. vyd. Praha: Státní pedagogické nakladatelství.

Tomášek, M. 2003. Překlad v právni praxi. 2. vyd. Praha: Linde.

Vídeňská úmluva o diplomatických stycích. [online] Ministerstvo zahraničních věcí České republiky [cit. 1. 1. 2018]. Dostupné z: https://www.mzv.cz/jnp/cz/o_ministerstvu/videnska_umluva_o_diplomatickych stycich.html.

Vláda ČR. 2018. „Legislativní pravidla vlády.“ [online] Vláda ČR [cit. 1. 1. 2018.]. Dostupné z: https:// www.vlada.cz/cz/ppov/lrv/dokumenty/legislativni-pravidla-vlady-91209/.

Zákon č. 89/2012 Sb., občanský zákoník. [online] Nové ASPI [cit. 1. 1. 2018]. Dostupné z: https:// www.noveaspi.cz/products/lawText/1/74907/1/2.

Zákon č. 155/1995 Sb., o důchodovém pojištění. [online] Nové ASPI [cit. 1. 1. 2018]. Dostupné z: https:// www.noveaspi.cz/products/lawText/1/43085/1/2/zakon-c-155-1995-sb-o-duchodovem-pojisteni.

Zákon č. 40/2009 Sb., trestní zákoník. [online] Nové ASPI [cit. 1. 1. 2018]. Dostupné z: https:// www.noveaspi.cz/products/lawText/1/68040/1/2. 
Zákon č. 255/2012 Sb., o kontrole (kontrolní řád). [online] Nové ASPI [cit. 1. 1. 2018]. Dostupné z: https://www.noveaspi.cz/products/lawText/1/77903/1/2/zakon-c-255-2012-sb-o-kontrole-kontrolnirad.

\section{O autorce}

Kateřina Hodková vystudovala obor Francouzský jazyk na Filozofické fakultě JU a obor Rízení a ekonomika podniku na Ekonomické fakultě JU. V současné době studuje na FF JU doktorský program Románské jazyky. Její specializací je odborný jazyk, zejména jazyk právní, a sémantika.

\section{Summary}

The present study concerns legal language and the relationships between languages from two different perspectives. The first one is the question of etymology, while the second one deals with the problems of translation and the equivalence of legal concepts. The goals of the research are as follows: the first is to confirm or to deny the presence of romanisms in the given corpus of Czech legal texts; the second is to demonstrate the process of the translation of legal terms including potential problems and their solutions. The third is to present the results of the translations, and the fourth is to examine official translations of the same terms in regard to their appropriateness while considering the equivalence of legal concepts and French legal terminology.

The methodology of the research can be described in the following manner: Firstly, romanisms, i.e. lexical units which originate from Romance languages, are identified in a given corpus with the help of etymological dictionaries and databases. Nový občanský zákoník (the New Civil Code - referred to below as NOZ) was chosen as the corpus for examination. Secondly, a set of terms which contain at least one romanism is selected. Thirdly, the legal concepts of selected terms are compared to legal concepts in French law and the degree of similarity is observed. Fourthly, appropriate translations of the selected terms are suggested, with special attention paid to legal concepts. Fifthly, the final translations are compared to translations from the official French translation of NOZ.

The research shows that NOZ (as of January 1, 2018) contains 32 different romanisms (i.e. of different etymology, as derivations of loanwords are counted only as one romanism), 23 of which are of French origin and 9 of Italian origin. No romanisms of Spanish, Portuguese or Romanian origin were found. Sixteen terms were chosen for the translation. The main sources of knowledge used for translations were existing French laws, although other sources (such as supranational law and dictionaries) were used if needed.

Several types of obstacles were encountered during the process, such as the differences between legal concepts, absence of legal definitions, rivalry of different possible translations, absence of a French term to name a concept and more. This study presents solutions to the problems; however, they are applied to concrete situations and are not general rules.

The sample of terms contained seven perfectly equivalent concepts (in other words, the concepts were identical in both Czech and French law). Another seven Czech concepts found their French counterpart to be partially equivalent. In that case, the concepts were similar in some aspects but different in others. In two cases out of sixteen, Czech concepts did not exist in French law and thus the situation was classified as having zero equivalence.

In some cases (zero equivalence, description of concept without a uniform term), it was necessary to create neologisms for the purpose of translation. Instead of creating new words, the author attempted to make use of the lexicon used in French laws. As for vocabulary, it can also be stated that the examined romanisms were conserved during the translation only in several cases.

In the final part of the study, the translations suggested by the author were compared to the official French translation of NOZ. In some cases, the translations were identical or similar to the extent that they were interchangeable. However, in some cases the official translations were barely comprehensible (when compared to the existing French terminology), probably due to word-for-word translation, which in the author's opinion might cause severe misunderstandings. For this reason, the author does not recommend the use of the official translations, as they do not respect the current state of French legal terminology.

To conclude, the research has confirmed the presence of romanisms of French and Italian origin in the corpus of NOZ, although other types of romanisms were absent. The sample set of terms used for 
translation purposes helped to illustrate various problems that can be encountered during the process of legal translation. Possible solutions are offered. The study also contains the final translations which were suggested, while special attention was paid to the equivalence of legal concepts and with respect to existing French legal terminology. An observation of the translations from the official French translation of NOZ showed that the official translation cannot be safely used as a dictionary for legal translations. 